\title{
Op metastasen gerichte behandeling van prostaatcarcinoom
}

\author{
Gisèle H. J. M. Leyten ${ }^{1}$ Inge M. van Oort ${ }^{2} \cdot$ Andries M. Bergman $^{3}$
}

Published online: 9 September 2019

(c) The Author(s) 2019

\section{Samenvatting}

Het aantal behandelmogelijkheden voor gemetastaseerd prostaatkanker en castratieresistent prostaatkanker is het laatste decennium belangrijk toegenomen. Van abirateron, enzalutamide, cabazitaxel en radium-223 is reeds een overlevingswinst aangetoond. In dit overzichtsartikel zullen we de huidige behandelmogelijkheden en de nieuwste ontwikkelingen op het gebied van gemetastaseerd prostaatcarcinoom bespreken, onder andere nieuwe indicaties zoals 'upfront' abirateron, en mogelijke toekomstige behandelingen zoals ${ }^{177}$ Lu-PSMA-617 behandeling, en de ontwikkelingen op het gebied van immunotherapie. Ook zullen wij de huidige gegevens over de meerwaarde van behandelen van de patiënt met oligometastasen bespreken.

Trefwoorden prostaatkanker $\cdot$ CRPC $\cdot$ behandelmogelijkheden $\cdot$ oligometastasen

\section{Metastasis-directed therapies for prostate cancer}

\begin{abstract}
The number of treatment options for metastasized prostate cancer and castration resistant prostate cancer has increased dramatically in recent years. Abiraterone, enzalutamide, cabazitaxel and radium-223 have been added to docetaxel as treatments with an overall survival benefit. In this article we will give an overview of current treatment options and the newest developments for metastasized prostate cancer treatments, including new indications such as 'upfront' abiraterone and possible novel treatments including ${ }^{177} \mathrm{Lu}$-PSMA-617 treatment and immunotherapy for prostate cancer. Moreover, we will discuss the current evidence for an added value for treatment of oligometastatic prostate cancer.
\end{abstract}

Keywords prostate cancer $\cdot$ CRPC $\cdot$ novel treatments $\cdot$ oligometastases

\section{Introductie}

Het aantal behandelmogelijkheden voor gemetastaseerd prostaatkanker en castratieresistent prostaatkanker (CRPC) is de laatste jaren sterk toegenomen. CRPC is het stadium van prostaatcarcinoom waarin de ziekte progressief is, ondanks serumtestosteronspiegels op castratieniveau,

dr. Gisèle H. J. M. Leyten

g.leyten@nki.nl

1 afdeling Urologie, Nederlands Kanker Instituut, Amsterdam, Nederland

2 afdeling Urologie, Radboud Universiteit Medisch Centrum, Nijmegen, Nederland

3 afdeling Medische oncologie, Nederlands Kanker Instituut, Amsterdam, Nederland wat zich uit als oplopende waarden van het serum-PSA, progressieve metastasering en het ontstaan van klachten. Sinds is aangetoond dat het leven van een gemetastaseerd CRPC-patiënt kan worden verlengd met docetaxelbehandeling, zijn er meerdere nieuwe therapieën beschikbaar gekomen en nieuwe indicaties voor deze behandelingen. Ook zijn meerdere nieuwe geneesmiddelen in klinische ontwikkeling. Daarnaast blijft de vraag of het zinvol is om oligometastasen te behandelen interessant en onbeantwoord. In dit overzichtsartikel worden de beschikbare therapieën en de nieuwste ontwikkelingen besproken. 


\section{Gemetastaseerd hormoongevoelig prostaatkanker}

\section{CHAARTED- en STAMPEDE-studie}

Patiënten met primair gemetastaseerd prostaatkanker en hoogvolume metastatische ziekte zoals gedefinieerd in de CHAARTED-studie ( $\geq 4$ ossale metastasen waarvan minimaal één buiten het axiale skelet of het bekken, of de aanwezigheid van viscerale metastasen) komen in aanmerking voor behandeling met docetaxel, naast het starten van androgeendepriverende therapie (ADT) [1]. In de CHAARTED-studie had $70 \%$ van de patiënten bij diagnose gemetastaseerde ziekte, terwijl de overige $30 \%$ metastasen hadden als uiting van een recidief. In de subgroep met hoogvolume metastatische ziekte, bleek dat de algehele overleving verbeterde met 17 maanden (van 32,2 naar 49,2 maanden $\mathrm{HR}=0,60 ; p=0,0008$ ) door het geven van upfront docetaxel. Er was geen significante overlevingswinst tussen beide behandelgroepen in de laagvolume metastatische ziektegroep, ook niet na een langere follow-up.

De resultaten van de later gepubliceerde Britse STAMPEDE-studie bevestigde deze resultaten. In de gehele groep van patiënten met een nieuw gediagnosticeerde ziekte (metastatisch, klierpositief of twee van de volgende: stadium T3/4, PSA $\geq 40 \mathrm{ng} / \mathrm{ml}$, Gleason 8-10) of een recidief na lokale behandeling (PSA $\geq 4 \mathrm{ng} / \mathrm{ml}$ met een verdubbelingstijd $<6$ maanden, PSA $\geq 20 \mathrm{ng} / \mathrm{ml}$, klierpositief of metastatisch) werd een overlevingswinst gezien van 10 maanden in de groep waarin 6 kuren docetaxel met prednison werd toegevoegd aan ADT ten opzichte van ADT alleen (81 vs. 71 maanden; $\mathrm{HR}=0,78 ;(95 \%-\mathrm{BI}=0,66-0,93) ; p=0,006)$ [2]. In de subgroep patiënten met metastasen was de overlevingswinst zelfs 22 maanden (43 vs. $65 ; \mathrm{HR}=0,73$; $p=0,002)$. In deze studie werd geen onderscheid gemaakt tussen hoog- en laagvolume gemetastaseerde ziekte.

De toevoeging van docetaxel aan de behandeling van patiënten die begonnen zijn met ADT, betekende dus een grote doorbraak, gezien de uitzonderlijke grote overlevingswinst van geselecteerde gemetastaseerde en hormoongevoelige patiënten. Echter, de populatie patiënten in de CHAARTED- en STAMPEDE-studies verschilden in belangrijke mate, wat de keuze voor een populatie met een indicatie voor docetaxeltoevoeging bemoeilijkt. Terwijl de winst in de CHAARTED-studie zat bij de patiënten met een hoogvolumeziekte, werd in de STAMPEDE-studie winst gezien bij alle gemetastaseerde patiënten, zonder onderscheid in volume. De commissie BOM adviseert op basis van deze gegevens dat er bij patiënten met een hormoongevoelig prostaatcarcinoom een indicatie is voor behandeling met zes kuren docetaxel naast ADT. De commissie stelt ook dat de behandeling met docetaxel van grotere meerwaarde lijkt als een patiënt prognostisch ongunstigere kenmerken heeft. In Nederland wordt veelal de toevoeging van docetaxel beperkt tot patiënten met een initieel en hoogvolume gemetastaseerde ziekte, conform de inclusiecriteria en de resultaten van de CHAARTED-studie.

\section{LATITUDE- en STAMPEDE-studie}

De LATITUDE-studie is een dubbelblinde placebogecontroleerde gerandomiseerde fase 3-studie. In totaal werden 1.199 patiënten met nieuw gediagnostiseerd gemetastaseerd prostaatcarcinoom gerandomiseerd tussen ADT plus abirateron $(1.000 \mathrm{mg}$ per dag) plus prednison $(5 \mathrm{mg}$ per dag) en tussen ADT plus placebo. De twee primaire eindpunten waren algehele overleving en radiologische progressievrije overleving. Er werden enkel patiënten met 'hoogrisico' prostaatkanker geïncludeerd. Dit werd in deze studie gedefinieerd als minimaal twee van de volgende criteria: Gleason-score $\geq 8$, minimaal 3 ossale metastasen (vastgesteld op CT en/of botscan) of de aanwezigheid van viscerale metastase(n). Bij de geplande interimanalyse was de algehele overleving significant langer in de abiraterongroep dan in de placebogroep (niet bereikt vs. 34,7 maanden; HR $=0,62(95 \%-\mathrm{BI}=0,51-0,76) ; p<0,001)$. In de abiraterongroep was de radiologische progressievrije overleving 18,2 maanden langer (33,0 vs. 14,8 maanden; $\mathrm{HR}=0,47(95 \%-\mathrm{BI}=0,39-0,55) ; p<0,001) \quad[3]$. Hiermee is upfront abirateron een optie geworden voor patiënten die voldoen aan 'hoogrisico' gemetastaseerd hormoongevoelig prostaatkanker. Daarnaast heeft de STAMPEDE-studie een arm waarin patiënten in de hormoongevoelige setting ADT plus abirateron $(1.000 \mathrm{mg}$ per dag) en prednison $(5 \mathrm{mg}$ per dag) kregen versus ADT plus placebo. Ook deze studie liet een langere algehele overleving zien bij patiënten in de abiraterongroep (184 vs. 262 patiënten waren overleden; $\mathrm{HR}=0,63(95 \%-\mathrm{BI}=0,52-0,76) ; p<0,001) \quad[4] . \quad$ Sydes et al. hebben de resultaten van de STAMPEDE-docetaxel en abirateronarmen met elkaar vergeleken [5]. Er werd in beide groepen een vergelijkbare algehele overleving gezien $(\mathrm{HR}=1,16(95 \%-\mathrm{BI}=0,82-1,65) ; p<0,001)$. Abirateron en docetaxel hebben een ander bijwerkingenprofiel, maar in beide groepen werd eenzelfde frequentie van graad 3-toxiciteit gerapporteerd.

De commissie BOM concludeert dan ook dat er een vergelijkbare overlevingswinst is door het toevoegen van abirateron plus prednison aan ADT, vergeleken met zes kuren docetaxel plus ADT. Wel is de behandelduur (en zijn dus ook de bijwerkingen) bij docetaxelbehandeling korter en brengt docetaxelbehandeling aanzienlijk minder kosten met zich mee. Dus stelt de commissie BOM dat een voorkeur voor docetaxel in deze populatie goed te verdedigen is met het oog op verantwoord medicatiegebruik. Bovendien is er onzekerheid over de gevolgen van langdurige extreme 
testosterononderdrukking voor botdichtheid en cognitieve functies.

\section{ARCHES-studie}

Op het jaarlijkse ASCO-GU-congres werden dit jaar de (voorlopige) resultaten van de ARCHES-studie gepresenteerd. In deze studie werden 1.150 patiënten met nieuw gediagnosticeerd gemetastaseerd prostaatcarcinoom gerandomiseerd tussen ADT plus enzalutamide (160 mg per dag) versus ADT plus placebo. Patiënten werden ingedeeld in laagvolume (37\%) en hoogvolume (63\%) gemetastaseerde ziekte zoals beschreven in de CHAARTED-studie, en in het wel $(18 \%)$ of niet $(82 \%)$ hebben ondergaan van docetaxelbehandeling. Primaire eindpunt is radiologische progressievrije overleving of overlijden. Patiënten in de enzalutamidegroep hadden een significant langere radiologische progressievrije overleving (niet bereikt vs. 19,4 maanden; $\mathrm{HR}=0,39$ ). In alle hiervoor genoemde subgroepen was de radiologische progressievrije overleving langer in de enzalutamidegroep. De algehele overlevingsdata zullen pas later gepresenteerd worden bij een langere follow-up.

\section{Niet-gemetastaseerd castratieresistent prostaatcarcinoom}

Bij patiënten met een stijgend PSA ondanks serumtestosteronspiegels op castratieniveau, bij wie metastasen bij beeldvorming ontbreken, spreken we van niet-gemetastaseerd CRPC [6]. In de praktijk is dit een kleine patiëntenpopulatie, zeker door de nieuwe ontwikkelingen op het gebied van beeldvormende technieken, zoals de PSMA-PET-scan. Op dit moment is een expectatief beleid gebruikelijk voor deze patiëntengroep. Onlangs zijn de resultaten van meerdere fase 3-studies bij patiënten met niet-gemetastaseerd CRPC bekend geworden, waarvan wij de belangrijksten hier zullen bespreken. In de PROSPER-studie werd enzalutamide versus placebo gerandomiseerd. Enzalutamide wordt over het algemeen redelijk goed verdragen, de meest voorkomende bijwerkingen zijn hypertensie, asthenie, moeheid en opvliegers. In de SPARTAN-studie werd apalutamide gegeven. Apalutamide is, net als enzalutamide, een androgeenreceptorantagonist, met een vergelijkbaar bijwerkingenprofiel. In de ARAMIS-studie werd darolutamide gegeven. Darolutamide is een androgeenreceptorantagonist met een hoge affiniteit voor de androgeenreceptor. Dit middel onderscheidt zich van andere androgeenreceptorantagonisten doordat het ook een hoge affiniteit heeft voor gemuteerde androgeenreceptoren. Daarnaast is er nauwelijks penetratie in de bloed-hersenbarrière, waardoor het mogelijk minder (centrale) bijwerkingen geeft. De afwezigheid van metastasen werd in al deze studies vastgesteld door een CT-thorax/ abdomen en een botscan. Het primaire eindpunt van deze studies was metastasevrije overleving, en niet algehele overleving (de gouden standaard als eindpunt in oncologische studies). Dit maakt de bewijsvoering voor de meerwaarde van deze middelen minder sterk.

\section{PROSPER-studie}

In de PROSPER-studie werden 1.401 patiënten met nietgemetastaseerd CRPC gerandomiseerd tussen enzalutamide (160 mg per dag) en placebo. Alle patiënten kregen daarnaast de gebruikelijke ADT en hadden serumtestosteronspiegels op castratieniveau. Patiënten in de enzalutamidegroep hadden 21,9 maanden langere metastasevrije overleving dan patiënten in de placebogroep (36,6 vs. 14,7 maanden; HR = 0,29 (95\%-BI =0,24-0,35); $p<0,0001)$ [7]. De algehele overleving was een secundair eindpunt en is nog niet bereikt. Bijwerkingen die leidden tot stoppen van de medicatie traden op bij $9 \%$ van de patiënten in de enzalutamidegroep en 6\% in de placebogroep. Graad 3-4-bijwerkingen traden vaker op in de enzalutamidegroep (31\% vs. $23 \%)$. De meest voorkomende bijwerkingen in de enzalutamidegroep waren moeheid (33\%), hypertensie (12\%), ernstige cardiovasculaire voorvallen $(5 \%)$ en een veranderde mentale conditie $(5 \%)$.

\section{SPARTAN-studie}

De SPARTAN-studie was in opzet vergelijkbaar met de PROSPER-studie, echter, in de SPARTAN-studie werden 1.207 patiënten met niet-gemetastaseerd CRPC gerandomiseerd tussen apalutamide $(240 \mathrm{mg}$ per dag) en placebo. Belangrijk te vermelden is dat patiënten met lymfekliermetastasen tot $2 \mathrm{~cm}$ onder de aortabifurcatie in deze studie als 'niet gemetastaseerd' werden geduid $(16,5 \%$ in de apalutamidegroep en $16,2 \%$ in de placebogroep), waardoor de resultaten van de apalutamidegroep wellicht gunstiger uitvallen. Het primaire eindpunt was metastasevrije overleving of overlijden. In de apalutamidegroep was de metastasevrije overleving 24,3 maanden langer dan in de placebogroep (40,5 vs. 16,2 maanden; $\mathrm{HR}=0,28(95 \%-\mathrm{BI}=0,23-0,35)$; $p<0,001$ ) [8]. Bijwerkingen die leidden tot stoppen van de medicatie traden op bij $11 \%$ van de patiënten in de apalutamidegroep en bij $7 \%$ van de patiënten in de placebogroep, een niet-significant verschil. Graad 3-4-bijwerkingen traden vaker op in de apalutamidegroep ( $45 \%$ vs. $34 \%$ ). Bijwerkingen die vaker optraden in de apalutamidegroep dan in de placebogroep waren, net als bij enzalutamide, moeheid $(30 \%$ vs. $21 \%)$ en opvallend frequent huiduitslag ( $24 \%$ vs. $6 \%)$. 
Hier staat een advertentie.

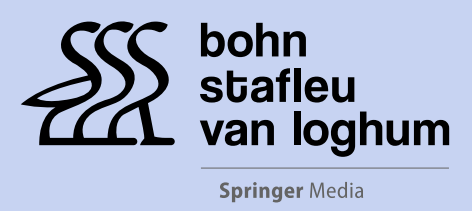

Houten 2019 
Hier staat een advertentie.

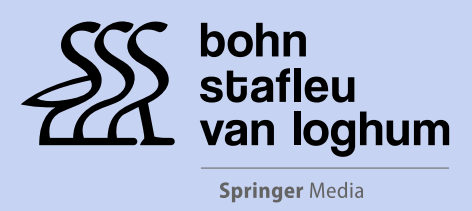

Houten 2019 


\section{ARAMIS-studie}

De ARAMIS-studie is een gerandomiseerde, dubbelblinde, placebogecontroleerde fase 3-studie waarin 1.509 patiënten met niet-gemetastaseerd CRPC werden geïncludeerd en is recent gepresenteerd op ASCO GU [9]. Patiënten werden gerandomiseerd tussen darolutamide $(2 \mathrm{dd} 600 \mathrm{mg})$ en placebo. Patiënten in de daralutamidegroep hadden een 22 maanden langere metastasevrije overleving ten opzichte van patiënten in de placebogroep (40,4 vs. 18,4 maanden; $\mathrm{HR}=0,41(95 \%-\mathrm{BI}=0,34-0,50) ; p<0,001)$. Darolutamide werd over het algemeen goed verdragen, en alleen moeheid kwam iets vaker voor in de darolutamidegroep dan in de placebogroep (12\% vs. 9\%). Bijwerkingen die leidden tot stoppen van de medicatie traden even vaak op in beide groepen ( $8,9 \%$ vs. $8,7 \%$ in de placebogroep). Graad 3-4bijwerkingen traden iets vaker op in de darolutamidegroep ( $25 \%$ vs. $20 \%$ ).

Hieruit concludeerde de commissie BOM dat voor zowel apalutamide als enzalutamide de behandeling van patiënten met niet-gemetastaseerd CRPC een verlenging van ruim 2 jaar van het primaire eindpunt metastasevrije overleving geeft, maar dat er geen aantoonbaar effect is op de algehele overleving. Aangezien niet de algehele overleving als primair eindpunt is onderzocht, en de toepasbaarheid voor de Nederlandse situatie zeer beperkt is, geeft de commissie hier verder geen advies over.

\section{Gemetastaseerd castratieresistent prostaatcarcinoom}

Het aantal behandelmogelijkheden voor gemetastaseerd CRPC is de afgelopen jaren sterk toegenomen. Sinds in 2004 is aangetoond dat het leven van een gemetastaseerde CRPC-patiënt kan worden verlengd door een docetaxelbehandeling, kan docetaxelbehandeling worden beschouwd als de 'gouden standaard' voor behandelingen van gemetastaseerd CRPC. In de TAX327-studie werd een overlevingswinst van docetaxel ten opzichte van mitoxantron aangetoond van 2,4 maanden (18,9 vs. 16,5 maanden; $\mathrm{HR}=0,76(95 \%$-BI $=0,62-0,94))$ en de kwaliteit van leven was in de docetaxelgroep beter dan in de controlegroep [10]. De aangetoonde overlevingswinst van docetaxelbehandeling heeft geresulteerd in de overtuiging dat behandeling van gemetastaseerd CRPC wel degelijk meerwaarde heeft. Alle nieuwe middelen worden gepositioneerd voor, tijdens of na docetaxelbehandeling. Welbekende middelen die sindsdien in Nederland beschikbaar zijn voor gemetastaseerd CRPC zijn onder meer enzalutamide, abirateron, cabazitaxel en radium-223.

Enzalutamide is een antiandrogeen met hoge affiniteit voor de androgeenreceptor. Daarnaast remt het de translocatie van de geactiveerde receptoren naar de celkern, en remt het de binding met DNA. In de AFFIRMstudie werden 1.199 eerder met docetaxel behandelde gemetastaseerde CRPC-patiënten gerandomiseerd tussen enzalutamide en placebo [11]. De algehele overleving was 4,8 maanden langer voor patiënten in de enzalutamidegroep $(18,4$ vs. 13,6 maanden; $\mathrm{HR}=0,63(95 \%-\mathrm{BI}=0,53-0,75)$; $p<0,001)$. In de PREVAIL-studie werden gemetastaseerde CRPC-patiënten die nog niet eerder waren behandeld met docetaxel gerandomiseerd tussen enzalutamide en placebo [12]. De algehele overleving was ook in deze studie significant beter in de enzalutamidegroep, een verschil van 2,2 maanden $(32,4$ vs. 30,2 maanden; $\mathrm{HR}=0,71(95 \%$ $\mathrm{BI}=0,60-0,84) ; p<0,001)$.

Abirateron zorgt voor CYP17-remming, waardoor de testosteronsynthese in de testes, bijnieren en prostaattumor wordt geremd en de serumtestosteronspiegel verder wordt verlaagd. Eerst werd in de COU-AA-301-studie een overlevingswinst aangetoond bij CRPC-patiënten die eerder met docetaxel waren behandeld. Patiënten werden gerandomiseerd tussen abirateron $(1.000 \mathrm{mg}$ per dag) plus prednison (2 dd $5 \mathrm{mg}$ ), versus placebo. De algehele overlevingswinst was 3,9 maanden $(14,8$ vs. 10,9 maanden; $H R=0,66$; $(95 \%-\mathrm{BI}=0,54-0,77) ; p<0,001)$. Daarnaast werd significante verbetering in kwaliteit van leven aangetoond. Vervolgens werd in de COU-AA-302-studie een overlevingswinst van 4,4 maanden in de abiraterongroep aangetoond bij patiënten die nog niet eerder met docetaxel waren behandeld $(34,7$ maanden vs. 30,3 maanden; HR $=0,81(95 \%$ $\mathrm{BI}=0,70-0,93) ; p=0,0033)$ [13].

Cabazitaxel is net als docetaxel een taxaan en een remmer van het microtubulimetabolisme. In de gerandomiseerde TROPIC-studie werden 755 eerder met docetaxel behandelde patiënten gerandomiseerd tussen maximaal $10 \mathrm{cy}-$ cli cabazitaxel $\left(25 \mathrm{mg} / \mathrm{m}^{2}\right)$ en de toen gebruikelijke post-docetaxelmogelijkheid mitoxantron $\left(12 \mathrm{mg} / \mathrm{m}^{2}\right)$ [14]. Patiënten in de cabazitaxelgroep hadden een significant langere algehele overleving van 2,4 maanden ( 15,1 vs. 12,7 maanden; HR =0,70 (95\%-BI=0,59-0,83); $p<0,0001)$. Patiënten in de cabazitaxelgroep hadden ook een significant betere progressievrije overleving van 1,4 maanden ( 2,8 vs. $1,4$ maanden; $p<0,0001)$ en een betere kwaliteit van leven. Cabazitaxel is alleen geregistreerd als behandeling van CRPC-patiënten die al eerder behandeld zijn met docetaxel.

Radium-223 is een radionuclide met biologisch gedrag dat vergelijkbaar is met dat van calcium, waardoor het zich voornamelijk bindt in en rond osteoblastische botmetastasen. Gezien de hoge energie en een zeer korte dracht van de alfadeeltjes in weefsel, worden osteoblastische botmetastasen selectief en intensief bestraald met een zeer lage stralingsbelasting van omliggende normale weefsels. Aangezien radium-223 alleen werkt op botmetastasen, wordt het niet aangeraden voor patiënten die ook viscerale of 
lymfekliermetastasen hebben of patiënten met myelumcompressie. In de gerandomiseerde, placebogecontroleerde ALSYMPCA-studie werden symptomatische ossaal gemetastaseerde CRPC-patiënten geïncludeerd, zonder viscerale of uitgebreide lymfekliermetastasen [15]. Ruim de helft van de patiënten had eerdere behandeling met docetaxel ondergaan, de overige patiënten waren niet voldoende fit voor docetaxel of had deze behandeling geweigerd. Er werd gerandomiseerd tussen zes giften radium-223 om de vier weken of placebo. De algehele overleving van met radium-223 behandelde patiënten bedroeg 14,9 maanden en die van de placebogroep 11,3 maanden, een winst van 3,6 maanden $(\mathrm{HR}=0,70(95 \%-\mathrm{BI}=0,58-0,83) ; p<0,001)$. Daarnaast waren er $34 \%$ minder skeletal related events en een betere kwaliteit van leven in de met radium-223 behandelde groep patiënten. Skeletal related events wordt gedefinieerd als radiotherapie van een pijnlijke botmetastase, nieuwe symptomatische pathologische fractuur, myelumcompressie of orthopedische chirurgie.

\section{ERA-studie}

Onlangs is in de ERA-studie aangetoond dat het toevoegen van radium-223 aan de behandeling van abirateron plus prednison bij gemetastaseerde CRPC-patiënten geen winst in symptomatische skeletal related events geeft [16]. Er waren zelfs significant vaker botfracturen in de radiumgroep (29\% ten opzichte van $11 \%$ in de placebogroep). Hierbij dient te worden opgemerkt dat slechts $41 \%$ van de patiënten botverstevigende behandeling kregen. Patiënten met botverstevigende medicatie hadden significant minder fracturen (15\% fracturen in de radiumgroep vs. $7 \%$ in de placebogroep) dan patiënten zonder botverstevigende medicatie $(37 \%$ fracturen in de radiumgroep, $15 \%$ in de placebogroep). Bovendien was er een trend naar oversterfte in de radiumgroep (algehele overleving van 30,7 vs. 33,3 maanden in de placebogroep; $\mathrm{HR}=1,195$ (95\%$\mathrm{BI}=0,950-1,505) ; p=0,1280)$. Derhalve wordt deze combinatie te allen tijde ontraden. Een studie naar de combinatie van radium-223 en enzalutamide van de EORTC (133GUCG; PEACE III) is daarna tijdelijk gestaakt en is onderzocht of hetzelfde probleem zich voordeed. Dit bleek niet het geval en de studie werd gecontinueerd met de verplichting van botverstevigende therapie voor alle deelnemende patiënten.

Er zijn helaas nauwelijks gegevens beschikbaar over de volgorde waarin bovenstaande medicatie het beste gegeven kan worden. In retrospectief onderzoek is aannemelijk gemaakt dat abirateron en enzalutamide in belangrijke mate kruisresistentie vertonen, wat te verklaren is door het feit dat beide remmers zijn van androgeenreceptorsignalering. Deze kruisresistentie geldt zowel voor abirateron na enzalutamide als voor enzalutamide na abirateron [17-20]. Dit zou kunnen betekenen dat het inzetten van deze middelen vlak na elkaar minder wenselijk is. Aangezien er geen betrouwbare klinische parameters bestaan om te voorspellen welke therapie op welk moment van de behandeling moet worden ingezet, is de hoop gevestigd op biomarkers. Idealiter kunnen we in de toekomst voor elke patiënt een behandeling op maat aanbieden. Zo is er beschreven dat het aantonen van splice-variant 7 van de androgeenreceptor (ARv7) in circulerende tumorcellen geassocieerd kan zijn met resistentie tegen abirateron en enzalutamide [21]. Het landelijk onderzoek in het kader van het Center for Personalized Cancer Treatment (CPCT) verricht DNA-onderzoek om te kijken of er aanknopingspunten zijn voor therapie op maat. CPCT verricht whole genome sequencing van patiënten met gemetastaseerde kanker (waaronder CRPC-patiënten). Zo ontstaat er een database die tegenwoordig al zo'n 2.000 patiënten bevat met allerlei soorten tumoren. Er wordt gekeken of er mutaties zijn die correleren met een response op specifieke behandelingen, bijvoorbeeld PARPremmers indien er BRCA1- of 2-mutaties zijn. Tot we meer bewijs hebben voor het gebruik van biomarkers in de keuze voor een behandeling, worden de keuzes momenteel met name gemaakt op basis van het bijwerkingenprofiel en comorbiditeit.

\section{Nieuwe middelen voor gemetastaseerd castratieresistent prostaatcarcinoom}

\section{VISION-studie}

In 2015 werd behandeling met ${ }^{177}$ Lu-PSMA-617 voor het eerst geïntroduceerd in een casereport uit Heidelberg (Duitsland) [22]. In dit casereport werd een spectaculaire afname van botmetastasen aangetoond na toediening van ${ }^{177}$ Lu-PSMA-617 bij een patiënt met ossaal gemetastaseerd CRPC. De PSMA-peptiden hechten zich aan alle PSMA tot expressie brengende cellen, waaronder prostaatcarcinoomcellen, zodat het daaraan gebonden lutetium-177 daar de radioactieve straling af kan geven. Sindsdien zijn er meerdere caseseries gepubliceerd, echter, level 1-evidence ontbreekt. De internationale, prospectieve, open-label, multicenter, gerandomiseerde fase 3-studie, de VISIONstudie moet daar verandering in brengen. Patiënten in deze studie hebben minimaal één eerdere behandeling met docetaxel en één nieuwe antihormonale therapie (enzalutamide of abirateron) gehad. Patiënten in de lutetiumgroep krijgen elke zes weken en maximaal zes cycli ${ }^{177} \mathrm{Lu}$-PSMA-617 toegediend. De controlegroep krijgt standaardzorg of abirateron of enzalutamide als zij die nog niet hebben gehad. De (voorlopige) resultaten worden in het jaar 2020 verwacht. De behandeling met ${ }^{177}$ Lu-PSMA-617 gaat vaak wel gepaard met ernstige speekselkliertoxiciteit (droge mond), 
waardoor dit middel vooralsnog alleen in 'uitbehandelde' gemetastaseerde CRPC-patiënten wordt onderzocht.

\section{KEYNOTE 199-studie en CHECKMATE 650-studie}

Vorig jaar werd op het ASCO annual meeting congress de resultaten van de KEYNOTE-199-studie en dit jaar op het ASCO-GU congres de CHECKMATE 650-studie gepresenteerd. Beide studies onderzoeken de rol van immunotherapie bij patiënten met gemetastaseerd CRPC. De KEYNOTE-199-studie onderzocht de effectiviteit van pembrolizumab bij 258 gemetastaseerd CRPC-patiënten, maar de resultaten waren teleurstellend. $\mathrm{Bij} 5 \%$ van de patiënten was er een complete of partiële respons, $18 \%$ had stabiele ziekte, en bij $60 \%$ was er progressieve ziekte. Mogelijk geeft pembrolizumab bij patiënten met mutaties in DNAherstellende genen (damage repair mutaties) een betere respons, maar dit is nog in de exploratieve fase. Het middel werd redelijk verdragen; er was bij $5 \%$ van de patiënten een graad 3-4 toxiciteit (o. a. vermoeidheid, huidreacties, colitis). De CHECKMATE 650-studie is een fase 2-studie met 90 patiënten naar de combinatie nivolumab $(1 \mathrm{mg} / \mathrm{kg})$ plus ipilimumab $(4 \mathrm{mg} / \mathrm{kg})$. Wat opvalt, is dat deze combinatie gepaard gaat met een zeer hoge mate van graad 3-4-toxiciteit, wat bekend is van dit schema in andere tumortypen. Hierdoor heeft slechts $29 \%$ van de patiënten de vier toedieningen van nivolumab plus ipilimumab kunnen volbrengen. Bijwerkingen waren met name diarree, vermoeidheid, huiduitslag, colitis en braken. Patiënten die nog niet eerder waren behandeld met docetaxel in de CRPC-setting (cohort 1) reageerden iets beter dan patiënten die al wel waren behandeld met docetaxel in de CRPC-setting (cohort 2). In cohort 1 had $25 \%$ van de patiënten een complete of partiële respons, ten opzichte van $10 \%$ in cohort 2 . Stabiele ziekte werd gezien bij $40 \%$ van de patiënten in cohort 1 , en bij $36 \%$ van de patiënten in cohort 2 . De data suggereren dat patiënten met PD-L1-expressie in $\geq 1 \%$ van de tumorcellen en tumoren die positief zijn voor DNA damage-repair-genenmutaties mogelijk beter reageren en dus als biomarker kan fungeren, maar dit moet nog verder worden onderzocht. $\mathrm{Al}$ met al staat de behandeling van CRPC-patiënten met immunotherapie dus nog ver van de kliniek.

\section{Oligometastasen}

Hellman en Weichselbaum introduceerden in 1995 de term oligogemetastaseerde ziekte als een apart stadium tussen lokaal en gemetastaseerde ziekte [23]. De term oligometastasen is een nogal heterogeen gebruikte term. Het aantal metastasen dat hiermee bedoeld wordt, staat niet vast omschreven; in de literatuur wordt variërend $\leq 3-5$ metastasen aangehouden [24]. Daarnaast kan het zowel de novo oligometastasen als oligorecurrent (het ontwikkelen van oligometastasen na eerdere in opzet curatieve behandeling) aanduiden. Of het zinvol is om oligometastasen te behandelen, staat nog niet vast. De enige gerandomiseerde studie naar de behandeling van oligorecurrent prostaatkanker is de STOMP-studie [25]. In deze fase 2-studie werden 62 patiënten met $\leq 3$ metastasen gerandomiseerd tussen een afwachtend beleid en stereotactische bestraling van alle zichtbare metastasen (op Choline PET-CT). Primair eindpunt was ADT-vrije overleving, dit werd in de radiotherapiegroep na 21 maanden bereikt, en in de controlegroep al na 13 maanden, een winst van 8 maanden $(\mathrm{HR}=0,60 ;(95 \%-\mathrm{BI}=0,40-0,90) ; p=0,11)$. De bestraling in de behandelgroep leverde weinig toxiciteit op en de kwaliteit van leven was in beide groepen niet verschillend. Hard bewijs dat de behandeling van oligometastasen winst in algehele overleving of progressievrije overleving geeft, is er dus (nog) niet. Tot op heden dient de behandeling van oligometastasen bij prostaatkanker dus individueel per patiënt in het multidisciplinair overleg te worden overwogen. De opzet van de behandeling van oligometastasen is momenteel het uitstellen van ADT, met als doel winst in kwaliteit van leven.

\section{Conclusie}

De behandeling van patiënten met gemetastaseerd prostaatkanker is een continu bewegend veld. Er komen in hoog tempo nieuwe therapieën en nieuwe indicaties beschikbaar, en beeldvorming wordt steeds nauwkeuriger. De keuze voor een behandeling wordt met name gemaakt op (interpretatie van) de beschikbare preklinische en klinische gegevens, karakteristieken van de patiënt en de ziekte, en de wensen van de patiënt. Er zijn weinig gegevens beschikbaar voor een beste volgorde van behandelingen. Mogelijk kunnen we in de toekomst zorg op maat geven door op basis van het genetisch profiel van de tumor te voorspellen wie baat gaat hebben van welke behandeling. Wat de rol van ${ }^{177} \mathrm{Lu}$-PSMA 617-therapie is in de behandeling van gemetastaseerd prostaatkanker moet de komende jaren duidelijker worden. Immunotherapie voor prostaatkanker staat nog in de kinderschoenen en is waarschijnlijk alleen zinvol in bepaalde subgroepen van patiënten.

Open Access This article is distributed under the terms of the Creative Commons Attribution 4.0 International License (http:// creativecommons.org/licenses/by/4.0/), which permits unrestricted use, distribution, and reproduction in any medium, provided you give appropriate credit to the original author(s) and the source, provide a link to the Creative Commons license, and indicate if changes were made. 


\section{Literatuur}

1. Sweeney CJ, Chen YH, Carducci M, Liu G, Jarrard DF, Eisenberger $\mathrm{M}$ et al. Chemohormonal therapy in metastatic hormone-sensitive prostate cancer. N Engl J Med. 2015;373(8):737-46.

2. James ND, Sydes MR, Clarke NW, Mason MD, Dearnaley DP, Spears MR, et al. Addition of docetaxel, zoledronic acid, or both to first-line long-term hormone therapy in prostate cancer (STAMPEDE): survival results from an adaptive, multiarm, multistage, platform randomised controlled trial. Lancet. 2016;387(10024):1163-77.

3. Fizazi K, Tran N, Fein L, Matsubara N, Rodriguez-Antolin A, Alekseev BY, et al. Abiraterone plus prednisone in metastatic, castration-sensitive prostate cancer. N Engl J Med. 2017;377(4): 352-60.

4. James ND, Bono JS de, Spears MR, et al. Abiraterone for prostate cancer not previously treated with hormone therapy. N Engl J Med. 2017;377:338-51.

5. Sydes MR, Spears MR, Mason MD, et al. Adding abiraterone or docetaxel to long-term hormone therapy for prostate cancer: directly randomised data from the STAMPEDE multi-arm, multistage platform protocol. Ann Oncol. 2018;29:1235-48.

6. Mottet N, Bellmunt J, Bolla M, et al. EAU-ESTRO-SIOG guidelines on prostate cancer. Part 1: screening, diagnosis, and local treatment with curative intent. Eur Urol. 2017;71:618-29.

7. Hussain M, Fizazi K, Saad F, et al. Enzalutamide in men with nonmetastatic, castration-resistant prostate cancer. N Engl J Med. 2018;378:2465-74.

8. Smith MR, Saad F, Chowdhury S, et al. Apalutamide treatment and metastasis-free survival in prostate cancer. $\mathrm{N}$ Engl $\mathrm{J}$ Med. 2018:378:1408-18.

9. Moilanen AM, Riikonen R, Oksala R, et al. Discovery of ODM201 , a new-generation androgen receptor inhibitor targeting resistance mechanisms to androgen signaling-directed prostate cancer therapies. Sci Rep. 2015;5:12007.

10. Tannock IF, Wit R de, Berry WR, et al. Docetaxel plus prednisone or mitoxantrone plus prednisone for advanced prostate cancer. N Engl J Med. 2004;351:1502-12.

11. Scher HI, Fizazi K, Saad F, et al. Increased survival with enzalutamide in prostate cancer after chemotherapy. N Engl J Med. 2012;367:1187-97.

12. Beer TM, Armstrong AJ, Rathkopf DE, et al. Enzalutamide in metastatic prostate cancer before chemotherapy. N Engl J Med. 2014;371:424-33.

13. Ryan CJ, Smith MR, Fizazi K, et al. Abiraterone acetate plus prednisone versus placebo plus prednisone in chemotherapy-naive men with metastatic castration-resistant prostate cancer (COU-AA-302): final overall survival analysis of a randomised, double-blind, placebo-controlled phase 3 study. Lancet Oncol. 2015;16:152-60.
14. Bono JS de, Oudard S, Ozguroglu M, et al. Prednisone plus cabazitaxel or mitoxantrone for metastatic castration-resistant prostate cancer progressing after docetaxel treatment: a randomised openlabel trial. Lancet. 2010;376:1147-54.

15. Parker C, Nilsson S, Heinrich D, et al. Alpha emitter radium223 and survival in metastatic prostate cancer. N Engl J Med. 2013;369:213-23.

16. Smith M, Parker C, Saad F, et al. Addition of radium-223 to abiraterone acetate and prednisone or prednisolone in patients with castration-resistant prostate cancer and bone metastases (ERA 223): a randomised, double-blind, placebo-controlled, phase 3 trial. Lancet Oncol. 2019;20:408-19.

17. Badrising S, Noort V van der, Oort IM van, et al. Clinical activity and tolerability of enzalutamide (MDV3100) in patients with metastatic, castration-resistant prostate cancer who progress after docetaxel and abiraterone treatment. Cancer. 2014;120:968-75.

18. Brasso K, Thomsen FB, Schrader AJ, et al. Enzalutamide antitumour activity against metastatic castration-resistant prostate cancer previously treated with docetaxel and abiraterone: a multicentre analysis. Eur Urol. 2015;68:317-24.

19. Loriot Y, Bianchini D, Ileana E, et al. Antitumour activity of abiraterone acetate against metastatic castration-resistant prostate cancer progressing after docetaxel and enzalutamide (MDV3100). Ann Oncol. 2013;24:1807-12.

20. Noonan KL, North S, Bitting RL, Armstrong AJ, Ellard SL, Chi KN. Clinical activity of abiraterone acetate in patients with metastatic castration-resistant prostate cancer progressing after enzalutamide. Ann Oncol. 2013;24:1802-7.

21. Antonarakis ES, Lu C, Wang H, et al. AR-V7 and resistance to enzalutamide and abiraterone in prostate cancer. $\mathrm{N}$ Engl J Med. 2014;371:1028-38.

22. Kratochwil C, Giesel FL, Eder M, et al. (1)(7)(7)Lu]Lutetium-labelled PSMA ligand-induced remission in a patient with metastatic prostate cancer. Eur J Nucl Med Mol Imaging. 2015;42:987-8.

23. Hellman S, Weichselbaum RR. Oligometastases. J Clin Oncol. $1995 ; 13: 8-10$

24. Foster CC, Weichselbaum RR, Pitroda SP. Oligometastatic prostate cancer: reality or figment of imagination? Cancer. 2019;125:340-52.

25. Ost P, Reynders D, Decaestecker K, et al. Surveillance or metastasis-directed therapy for oligometastatic prostate cancer recurrence: a prospective, randomized, multicenter phase II trial. J Clin Oncol. 2018;36:446-53.

dr. Gisèle H.J.M. Leyten uroloog

dr. Inge M. van Oort uroloog

dr. Andries M. Bergman medisch oncoloog 